\title{
Crowdfunding in a Context of Financing Firms Through Their Life Cycle
}

\author{
Tin Horvatinovic ${ }^{*}$ \\ Silvije Orsag ${ }^{* *}$
}

\begin{abstract}
In this paper we first present some developed theories of financing that firms might accord with in their development stages. The framework, assumptions and predictions of the capital structure of firms in each theory is shown. Afterwards, crowdfunding, as a fairly new source of financing that is increasing significance, is described and is differentiated on the basis of the type of return on investment for the outside investors. In recent literature there have been models that introduce crowdfunding in the framework of financing firms through their life cycle stages. We point the difficulty of encompassing crowdfunding in the mentioned models because of characteristics that are unique to it from the perspective of the investor and the firm. While it is not surprising that crowdfunding is used in development stages, these characteristics make it difficult to construct a model of financing firms that has traditional means of financing and crowdfunding.
\end{abstract}

Keywords: crowdfunding; small business financing; life cycle of firms

JEL Classification: G32, L26

\section{Introduction}

The theory of the life cycle of a firm was first constructed by (Penrose, 1952) and its main purpose is to describe the development of a firm through the stages it passes during its life. The life cycle of a firm can be described by different stages that are results of different internal and external factors (Dickinson, 2011).

Every firm that grows goes through some stages of development that can be connected to the development of a product that it is producing and selling, although the firm does not develop in accordance with the development of that product. By transi-

\footnotetext{
* Tin Horvatinović is at University of Zagreb, Faculty of Economics and Business, Zagreb, Croatia. ${ }^{* *}$ Silvije Orsag is at University of Zagreb, Faculty of Economics and Business, Zagreb, Croatia.
} 
tioning from one stage of development to another a firm goes through various forms of crises which demands certain changes and makes planning of future growth more difficult for the owner and/or manager (Scott \& Bryce, 1987).

Despite a large number of theoretical and empirical research that were conducted on the subject of the firms life cycle, an agreement about the number of phases and the number and structure of factors that influence the life cycle has not been reached. One possible cause of the of lack of a consensus is the fact that firms, in most cases, produce more than one product, of which each one can be in a different stage of its own development (Dickinson, 2011).

Although different parts of a firm can be studied and analyzed in different stages of its life cycle, for the purposes of this article the capital structure and the factors that influence it will be analyzed. In that framework the objective is to scrutinize the possibility of using crowdfunding as a new source of financing firms' business activities.

\section{Capital Structure of a Firm}

Albeit the first researches on the capital structure of a firm began in 1952 (Durant) the turning point in that field was the MM model (Modigliani \& Miller, 1958). In their work they proved that on an efficient market which has all the features of a perfect market, the use of leverage does not affect or determine the value of a firm, but that the primary factor that determines the value are investments which the firms undertakes, or in other words, that what the firm earns. In that sense the capital structure does not determine the average cost of capital either. In their later work Modigliani and Miller (1963) made a correction of the mentioned proof introducing one imperfection of the real world, corporate income tax, and have showed that the primary advantage of debt is the tax shield which is created by the interest that is paid. On the basis of that correction in 1963. Modigliani and Miller have set a foundation for further "laboratory" research on the capital structure in which is possible to introduce different imperfections of the real world in a basically perfect market and specify their influence on the value of a firm in isolation of other factors.

\section{Trade-off Theory}

On the basis of the so-called MM revolution and the laid foundation of research in the correction of the initial model of the irrelevance of the capital structure trade-off theory was developed which proves the existence of an optimal capital structure of capital as a compromise between the benefits and the costs of debt, mainly as a compromise between the benefits of the tax shield, made possible by interest, and the increase the cost 
of debt due to the increased risk of financial distress that could cause and/or exuberate agency costs and costs of bankruptcy (Kraus \& Litzenberger, 1973). In wider models of trade-off theory the risk of reoccurrence of tax shield, personal taxes and transaction costs and the problem of free cash flows are also considered (Orsag, 2015).

Trade-off theory makes possible the isolation of key factors that determine the capital structure of the firm. According to the theory the ability to acquire debt mainly depends on the size and structure of the firm's assets that gives power to the guarantees on debt and the ability the renew tax shields that primarily depends on the firm's stability and earning power, or in other words the instability of past and future earnings. In addition, the ability to acquire debt depends on information asymmetry, generally, and how it shows itself in specific market segments, in particular (Rajan $\&$ Zingales, 1998). Since this paper is concentrated on financing small and medium firms, the trade-off theory highlights the problems that small firms face in regard to financing because of their poor assets, poorly documented past and higher risk of future business and a high level of asymmetry of information for a large number of potential investors.

\section{Pecking Order Theory}

The name pecking order was coined by Myers (1984), although the phenomenon of preferring of internal financing for investment projects was detected and explicitly stated by Fisher and Donaldson in 1962. The theory is based on asymmetry of information in which investors, as carriers of the weaker information, interpret actions of managers, carriers of more accurate information, as signals they send to the public. Retained earnings are regarded as the best signal. Acquiring debt also carries positive signals, especially if it is a result of valuable guarantees, so that for public corporations issuing bonds is a fundamental method for long term borrowing. Issuance of capital, or stocks, according to this theory, sends negative signals, unless it is initial public offering which accommodates the company going public (Orsag, 2015).

Pecking order theory leaves aside the theoretical modeling of the optimal capital structure. Starting from the behavior of the firm in regards to choices of financial means and managerial conservatism it shows that internal financing is the first choice. Because of the asymmetry of information and signaling intentions and financial situation, financing the firm by debt is more favorable than the issuance of stock. Agency problems also affect pecking order theory. Depending on which aspect of problem is highlighted, it is possible to make different conclusions with regards to the financial choices that are available to the management of public corporations. Pecking order theory should not be viewed as an opposite to trade-off theory. According to pecking order theory there is no optimal capital structure and the firm will firstly use resources that lower adverse selection costs (Castro et al., 2016). In other words, 
the firm will use internal cash flows for financing investment projects with positive net present value in order to minimize signaling problems (Bhaird \& Lucey, 2007). So, the theory predicts that the firm will first use retained earnings, after that debt and lastly issuing stock (La Rocca et al., 2009).

\section{Financing Small and Medium Firms}

The conclusions from the theories of the capital structure developed on the analysis of public corporations, from the aspect of financial theory and market efficiency, can be fully applied to small and medium firms. In that context a small firm is nothing more than a small big firm. Small firms in real world conditions are not really just a small big firm, because there are key differences with regard to financial management and potential investors (Orsag \& Dedi, 2011).

\section{The Scarcity of Financial Resources}

From the standpoint of potential investors, there is a significant difference in ownership of equity of big and small firms because of their different levels of liquidity. The liquidity of stocks or ownership stakes is in the domain of fiction or theoretical assumptions. Different levels of liquidity stocks have an impact on the cost of capital, sources of financing and the liquidity of the business of small and big firms. The illiquidity of ownership stakes of small and medium firms logically raises their cost of capital above the level of public corporations and there is concern in the ability to even asses and use them in evaluation of capital projects in that kind of firm. The mentioned illiquidity of shares restricts the sources of financing of small and medium enterprises which are mainly oriented on self-financing and can additionally raise debt in banks or other specialized financial institutions. Those additional levels of debt are, generally, related with personal guarantees of owners of small and medium firms and with the reduction of flexibility of doing business. All that even more decreases the liquidity of small and medium enterprises.

While in big public corporations professional managers, who are experts, govern the corporation as agents of the owners, in small firms, generally, the owners are in the double role of owner and manager or in other words owners are also entrepreneurs. The potential consequences of that managerial situation are that goals of the firm can change and that owners do not have an adequate understanding of financial management and/or the tools of financial analysis. All of that makes it harder to predict the future outcomes of small and medium firms. In addition, their chances of survival come into question, which along with daily problems of solvency and liquidity becomes the primary goal of these firms. 
The unique characteristics of small and medium firms have a significant effect on the process of decision making about the capital structure, the optimal level of capital structure and its modeling. So, for instance since small and medium firms go through different stages during their development, there probably is no unified theory of capital structure, but it is a function of the life cycle of the firm so that the optimal level of the capital structure is changed in different stages of the firm's life cycle (Ang, 1991). Furthermore, empirical studies that try to explain the capital structure of small and medium firms are not complete if personal risk of the owners is not included because the total assets consist of business and personal assets of the owner (Ang et al., 1995). It should also be noted that small and medium firms rely on private markets in order to assure the resources for their business, and which represents a reduction in available choices of financial means in comparison with the big corporations (Gregory et al., 2005).

From these observations the conclusion is that during their development small and medium firms go through different stages and in each stage they use different forms of financing. In the scientific literature there are a lot of different approaches in explaining the behavior of these firms and they predict different patterns of behavior. In this article three will be analyzed: trade-off theory, pecking order theory and the capital structure life stage theory. For the analysis of other theories look for instance in (Harris \& Raviv, 1991).

\section{Capital Structure Life Stage Theory}

Capital structure life stage theory begins with the assumption of the lack of information of small and medium firms. Namely, of all of the differences between big and small (medium) firms lack of informational transparency is the most significant one in terms of financing the business. The reasons for this difference are that small firms do not go through such rigorous auditing process, they do not issue securities that are regularly priced on the market, they cannot effectively signal their quality to financial institutions and the public and the contracts between them and their suppliers are not publicly available (Berger \& Udell, 1998).

Starting from the lack of transparency of small and medium firms, in the beginning of their development they cannot finance their operations from outside sources because of the lack of internal sources. They can finance from outside sources when retained earnings reach a level that can support outside financing (Berger \& Udell, 1998). Looking at it differently, in the beginning of their development small and medium firms have high business risk and because of that they do not have the capacity to increase their financial risk. After a period of growth and the reduction of business risk the firm can take on more financial risk while in the later stages business risk will raise again which will lower the dependency on debt (Frielinghaus et al., 2005). 
From the above mentioned the conclusion is that the use of debt will become larger during the life of the firm because small and medium firms will not have as good access to significant financial resources as do big corporations have (La Rocca et al., 2009). Firms will, according to the capital structure life stage theory have a trajectory of leverage low-high-low during their development (Frielinghaus et al., 2005).

The assumption of the pecking order theory is that the use of debt is determined by the ability of the firm to generate and keep cash flows and the opportunities to invest in investment projects (Teixeira $\&$ dos Santos, 2014). In that sense this, because of the inadequate level of retained earnings in their beginnings firms will have a trajectory of leverage of high-low-high during their development (Castro et al., 2016). The fact that the firm will have high levels of leverage seems unrealistic at first, but borrowing can come from families and friends (groups that are significant sources of financing in early stages) and also from financial institutions since the owner has unlimited liability, which is sometimes explicitly stated as collateral (Berger \& Udell, 1998). The size of debt incurred from banks is much larger than the amount provided by friends and families, from which follows that small firms mostly use formal sources of financing (Robb \& Robinson, 2010).

In contrast to the pecking order theory, trade-off theory predicts that leverage of firms will follow a low-high-low trajectory during their development (Frielinghaus et $a l ., 2005)$. Namely the theory assumes that the firm chooses the level of debt by comparing the benefits and the costs of it (Myers, 1984). An interesting fact is that within the trade-off theory firms use some sort of pecking order theory while choosing sorts of debt. In their empirical research (Blackwell \& Kidwell, 1988) show that the choice of the type of debt is a function of lowering transaction costs, so small firms will use private markets (mainly banks) while big corporations will use public markets.

\section{Crowdfunding}

Crowdfunding can be defined as an attempt of an entrepreneur, individuals and/or groups, which are culturally, socially or profitably oriented, for financing investment projects by a large number of individuals through the Internet, who give small contributions, without standard financial intermediaries (Mollick, 2014). The big difference between crowdfunding and other „classical forms” of financing is that in crowdfunding financial intermediaries are not involved. Financial intermediaries are institutions who, among other things, carry the process of contracting, monitoring and screening (Berger \& Udell, 1998). In the case of crowdfunding, the role of connecting surplus spending units with the deficit spending units is taken by the internet platform and they do not conduct the above mentioned activities. Precisely because of the fact that uninformed investors make small contributions and do not conduct consulting and supervision activities, there is some doubt as to the long term success rate 
of firms who finance themselves by crowdfunding (Chemmanur \& Fulghieri, 2014). However, since there are a large number of small investors who invest individually small amounts of money, the risk is dispersed because, in most cases, the risk from one financial institution is transferred to a large number of individuals (BBVA, 2013).

Firms use different ways and instruments of crowdfunding; therefore it can be classified in different ways. For instance (Hass et al., 2014) use a holistic approach in their crowdfunding classification, while (Rossi, 2014) categorizes crowdfunding from the aspect of the development of the investment project. In this paper crowdfunding will be categorized in five groups according to (Harrison, 2013) on the basis of the type of return on investment for the outside investors.

1. Donation model. Investors here invest money in firms without the expectation of any financial return or return on investment. Although it is a model of financing where investors donate money, this form is not exclusively oriented on nonprofit organizations.

2. Reward model. The investor in this model gets a prize from the firm in the shape of a product that the entrepreneur is not making.

3. Pre-purchase model. This model is similar to the second model, but in this model the investor receives a product that the firm makes and which is still in the development phase. It can be said that the investor gets a prototype. Besides financing, the firm additionally conducts market research because on the basis of success of the crowdfunding campaign it can conclude about the interest of potential investors in that product. This model is appropriate for innovative firms and small products (Rossi, 2014).

4. Lending or peer-to-peer model. In this model the investors expect a return and interest because they are giving a loan to the firm. Since it is a loan, investors do not invest in the capital of the firm (Čondić-Jurkić, 2015). In comparison to previous models the drawbacks are that it is harder to carry out a market research and there are legal uncertainties in respect to the insurance of individuals and firms.

5. Equity model. In this model investors invest in the capital of the firm through buying securities or financial instruments. Since there is no secondary market for these securities, investors make a return on investment by buying shares from the management or from other firms during the takeover (Čondić-Jurkić, 2015).

\section{Crowdfunding and the Firm's Life Cycle}

Before the analysis of the possible position of crowdfunding in the firm's life cycle, it should be mentioned that there are certain connections between crowdfunding and other traditional forms of financing. One such attempt is found in Motylska-Kuzma 
(2015) where an analysis was made of the connection of the cost of capital (vertical axis) and the impact of control (horizontal axis).

Figure 1. Sources of capital and crowdfunding

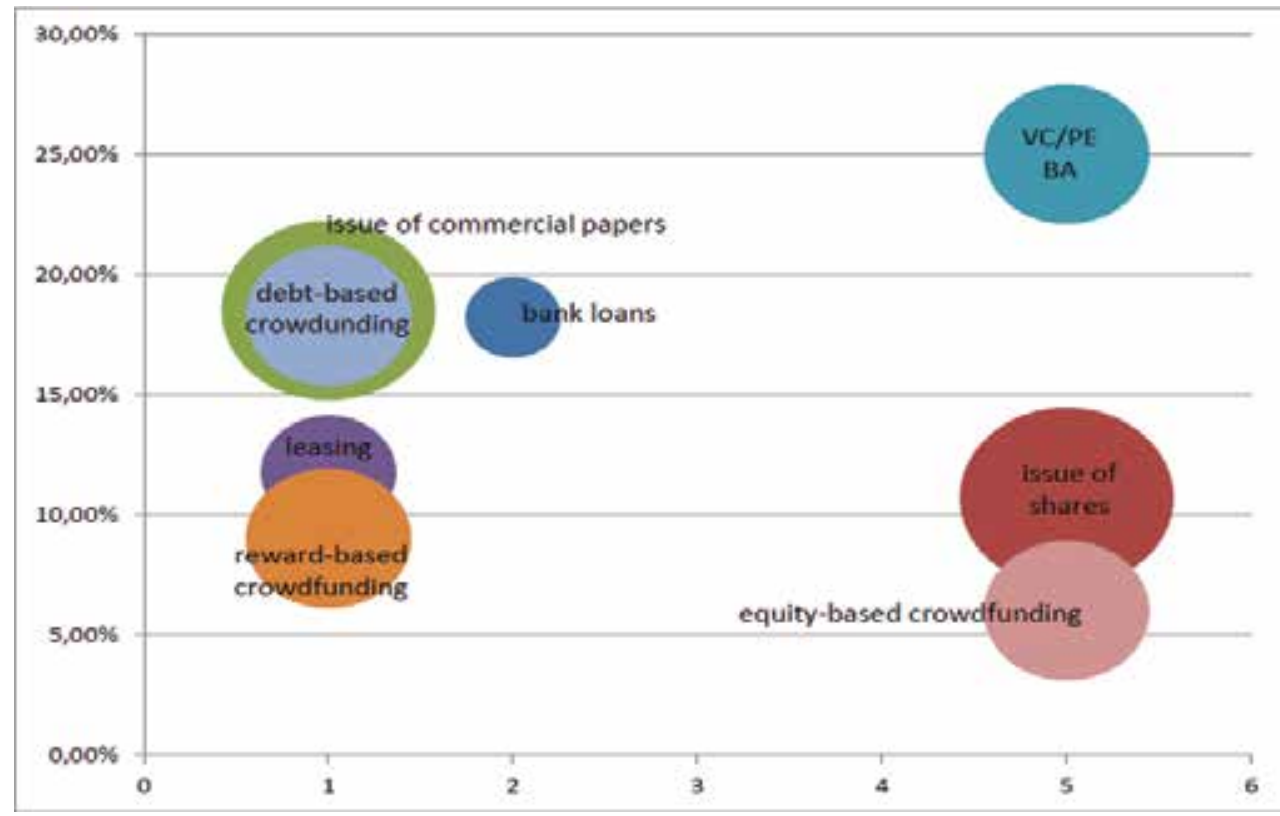

Source: Motlylska-Kuzma (2015)

The conclusion that peer-to-peer model has similarities with commercial papers and loans from banks and that there are similarities between the equity model and issuance of shares is not surprising. The drawback to this model is the conclusion that the reward based model can be regarded as a substitute for the leasing because, paper the former can have the goal to conduct the market analysis, while it is impossible by the latter. Furthermore, it can be postulated that leasing can be a complement to peer-to-peer model because there is complementarity between debt and leasing (Ang \& Peterson, 1984). (Motylska-Kuzma, 2015) merges the donation model with the reward based model.

With the rise of importance of crowdfunding as an alternative way of financing firms and the growth of interest in research on this subject, in the scientific literature crowdfunding was incorporated in the theoretical framework of financing firms through their life cycle. In the graph crowdfunding is shown as a single source in the life cycle of the firm. 
Figure 2. Venture financing lifecycle

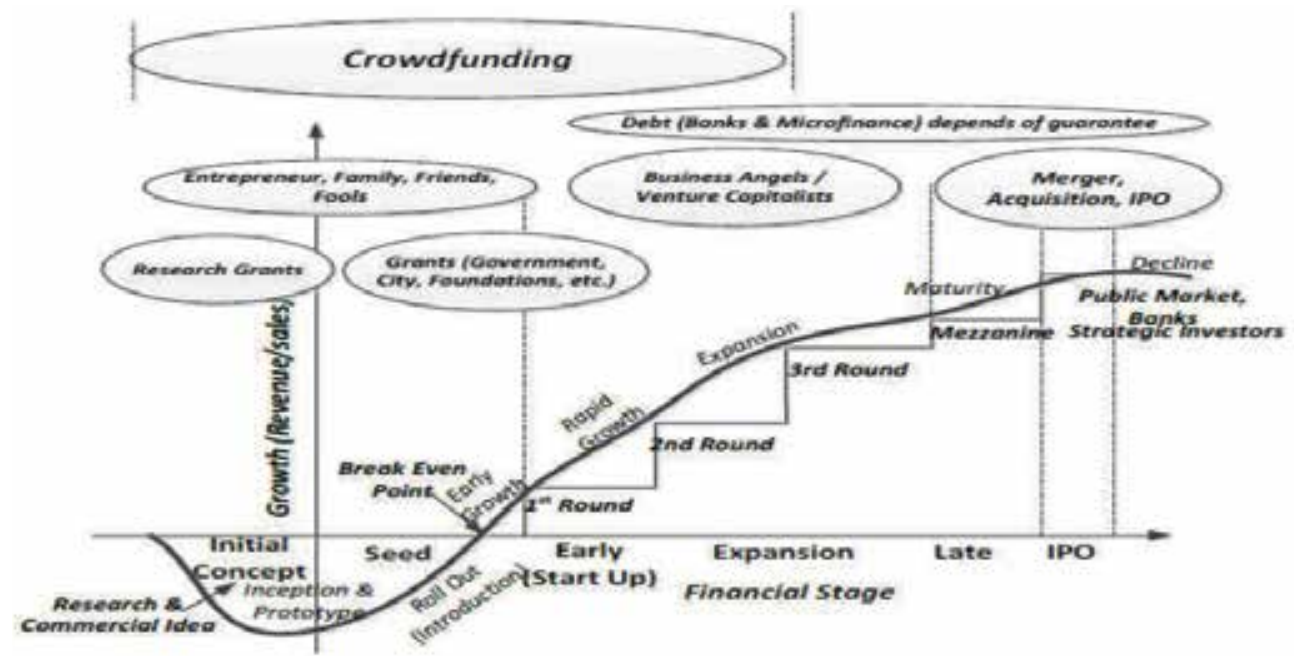

Source: Rossi (2014), according to: (Lasrado \& Lugmayr, 2013)

In this model, as in most models that are found in the literature, crowdfunding is used by firms who are still in development, which means that it will be used by firms in stages from the point of the establishment of the firm up till the maturity stage. (Collins \& Pierrakis, 2012) arrive at the same conclusion and they state that firms use crowdfunding after they have exhausted resources given from FFF (friends, families and fools) and in the period of development where the firm is not attractive enough for venture capitalist funds and after business angels stop being active.

In the mentioned models crowdfunding is looked at as a whole, although there are different forms of crowdfunding that, because of their uniqueness, would fit in different stages of development. The model which incorporates some forms of crowdfunding and their connection with the life cycle of startups is developed by (Paschen, 2017). 
Figure 3. Startup stages and crowdfunding

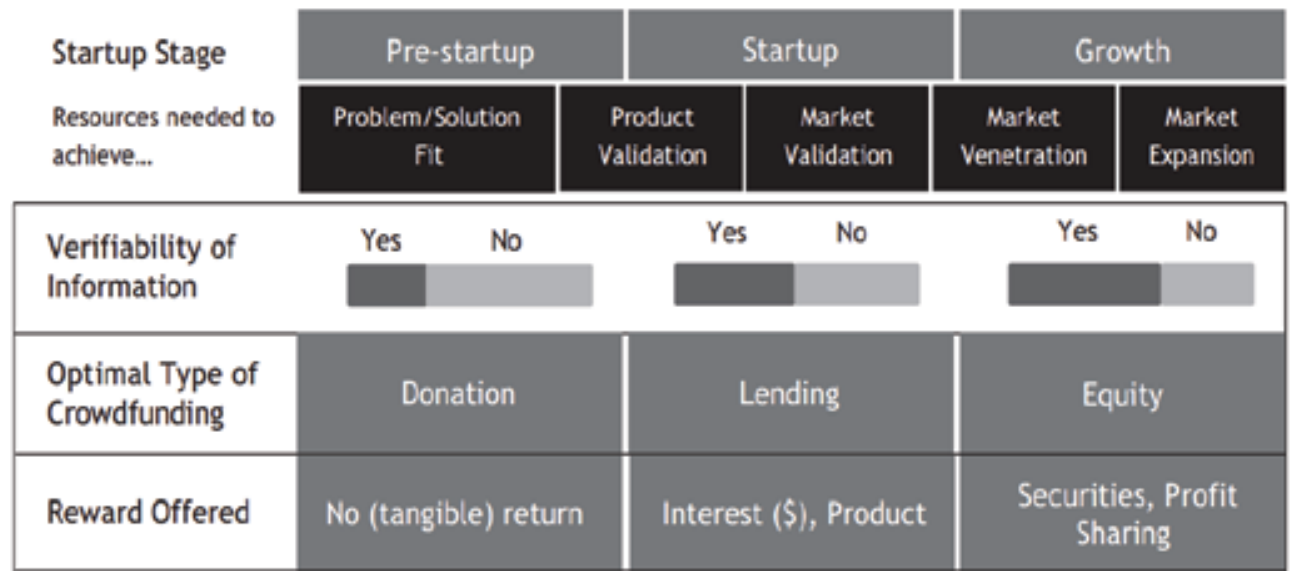

Source: Paschen (2017)

Paschen (2017) uses the model of the life cycle that has three stages and was developed by (Churchill \& Lewis, 1983) and the donation model is merged with the reward model, as is the case in (Motylska-Kuzma, 2015). This model is primarily concerned with the life stage cycle of a product, not of the whole firm. Although the donation model, by its characteristics, fits in the phase of the development of the business ideas (Paschen, 2017) there is a question of how many firms can actually use this model. Namely, the donation model is most commonly used for investment projects in which there are certain social benefits, in other words it is not enough to assume that investors will invest and be less disappointed of the unsuccess of the project just because it is a small amount that they contribute. Furthermore, (Paschen, 2017) excludes the pre-purchase model which represents a big portion of all funds collected in crowdfunding campaigns (Rossi, 2014).

Belleflamme et al. (2014) set the theoretical framework and conduct an analysis of the factors that affect the decision on whether to use the pre-purchase model or the equity model. In that context the firm can use a strategy of price discrimination and will use the pre-purchase model for lower amounts of needed capital for the project and after a certain level of needed capital it will use the equity model. Their paper points out the difficulty of putting crowdfunding in a framework of the life cycle along with traditional forms of financing. The reason for that is the complexity and multidimensionality of crowdfunding. The reasons for which firms use crowdfunding differ from those for which they use traditional means because in crowdfunding campaign they can also get additional information and feedback on their products (Agrawal et al., 2014).

From the investors' point of view, individuals who invest through crowdfunding have different motives from those of institutions specialized for financing the firms. Individuals participate in crowdfunding campaigns because they are interested in 
financial returns, are oriented on innovation, are interested in interaction with other investors and identify themselves with the firm and/or product in which they invest (Ordanini et al., 2011). The returns on investments are also based on different assumptions. For instance, business angels make large investments and they draw benefits from nonstandard contracts, while in equity crowdfunding such contracts would cause too big transaction costs which are why the contracts are most commonly made in standard forms (Hornuf \& Schwienbacher, 2015).

From the above mentioned follows the conclusion that it is difficult to incorporate crowdfunding in any theory of financing firms through their life cycle since the assumptions for these models are not met for crowdfunding on the demand and supply side. Besides that, in crowdfunding campaigns the problems that are present in the theories of financing can get more emphasized. So for example the problem of information asymmetry in the pecking order theory can be more severe in equity crowdfunding because individual investors do not have enough knowledge and experience for the evaluation of investment projects and/or of the firm. Therefore firms will try to signal their quality even more in equity crowdfunding than in for example business angels, and there is the theoretical possibility that they will not be successful in crowdfunding campaigns even though they could potentially be profitable firms (Ahlers et al., 2015)

\section{Conclusion}

In recent years there has been a significant rise in the use of crowdfunding in the world. In 2012 total amount of collected funds in crowdfunding was 2.7 billion dollars and in 2015 that rose to 34.4 billion dollars (Massolution, 2016). With the rise of significance of crowdfunding the number of scientific research on that topic has also risen. One of the topics was the comparison of crowdfunding with the traditional forms of financing. In this paper crowdfunding was presented in the context of financing small and medium firm through their life cycle.

Even though the theoretical frameworks that incorporate crowdfunding are still developing, in this paper the difficulties, not the impossibility, were pointed out in trying to fit crowdfunding into the context of financing firms through their life cycle. The reasons for this conclusion come from the fact that there are significant differences on the demand and supply side. On the demand side, firms use crowdfunding for additional reasons than they use traditional sources of financing. From the supply side, the investors have different levels of information, different motives for investing and a different principle of realizing profits and risk dispersion. Before trying to incorporate crowdfunding into models of financing firms through their life cycle further theoretical models and empirical research need to be done so that a consensus on the preference of different forms of crowdfunding is reached. 


\section{REFERENCES}

Agrawal, A., Catalini, C. \& Goldfarb, A. (2014). Some Simple Economics of Crowdfunding. Innovation Policy and the Economy. 14(1), 63-97. DOI: 10.3386/w19133

Ahlers, G., Cumming, D., Günther, C. \& Schweizer, D. (2015). Signaling in Equity Crowdfunding. Entrepreneurship Theory and Practice. 39(4), 955-980. DOI: 10.1111/etap.12157

Ang, S. (1991). Small Business Uniqueness and the Theory of Financial Management. Journal of Small Business Finance. 1(1), 1-13. Retrieved February 25, 2017, from: http://digitalcommons.pepperdine.edu/cgi/viewcontent.cgi?article $=1108 \&$ context $=$ jef

Ang, S., Lin J.W. \& Tyler, F. (1995). Evidence on the Lack of Separation between Business and Personal Risks among Small Businesses. Journal of Small Business Finance. 4(2), 197-210. Retrieved February 25, 2017, from: http://digitalcommons.pepperdine.edu/cgi/viewcontent. cgi?article $=1176 \&$ context $=$ jef

Ang, S. \& Peterson, P. (1984). The Leasing Puzzle. The Journal of Finance. 39(4), 1055-1065. DOI: $10.2307 / 2327612$

BBVA Research (2013). Economic Outlook, Second Quarter 2013. Retrieved February 28, 2017, from: https://www.bbvaresearch.com/KETD/fbin/mult/1306_EEUUOutlook_2Q13_tcm348392269.pdf

Belleflamme, P., Lambert, T. \& Schwienbacher, A. (2014). Crowdfunding: Tapping the Right Crowd. Journal of Business Venturing. 29(5), 585-609. DOI: 10.2139/ssrn.1578175

Berger, A. \& Udell, G. (1998). The Economics of Small Business Finance: The Roles of Private Equity and Debt Markets in the Financial Growth Cycle. Journal of banking and Finance, 22(6-8), 613-673. DOI: 10.1016/S0378-4266(98)00038-7

Bhaird, C. \& Lucey, B. (2007) The Financial Growth Life Cycle: An Empirical Examination of Irish SMEs. Retrieved February 19, 2017, from Social Science Research Network: https://ssrn. com/abstract=991296 DOI: 10.2139/ssrn.991296

Blackwell, D. \& Kidwell, D. (1988). An investigation of cost differences between public sales and private placements of debt. Journal of Financial Economics. 22(1), 253-278. DOI: 10.1016/0304405X(88)90071-2

Castro, P., Tascón, M. \& Amor-Tapia, B. (2016). The role of life cycle on the firm's capital structure. Pecvnia Revista de la Facultad de Ciencias Económicas y Empresariales. 19, 131-155. 10.18002/pec.v0i19.3585

Chemmanur, T. \& Fulghieri, P. (2014). Entrepreneurial Finance and Innovation: An Introduction and Agenda for Future Research. Review of Financial Studies. 27(1), 1-19. DOI: 10.1093/rfs/ hht063

Churchill, N.C. \& Lewis, V.L. (1983). The five stages of small business growth. Harvard Business Review. 61(3), 30-50.

Collins, L. and Pierrakis, Y. (2012). The venture crowd crowdfunding Equity Investment into Business. Nesta. Retrieved March 1, 2017, from: https://www.nesta.org.uk/sites/default/files/the_ venture_crowd.pdf

Čondić-Jurkić, I. (2015). Crowdfunding - what do we know about this alternative source of financing?. Notitia-časopis za održivi razvoj. 1(1), 71-83.

Dickinson, V. (2011). Cash Flow Patterns as a Proxy for Firm Life Cycle. The Accounting Review. 86(6), 1969-1994. DOI: 10.2308/accr-10130

Fisher, A. J. \& Donaldson, G. (1962). Corporate Debt Capacity: A Study of Corporate Debt Policy and the Determination of Corporate Debt Capacity. The Journal of Finance. 17(3), 554-555. DOI: doi.org/10.2307/2977084 
Durand, D. (1952). Cost of Debt and Equity Funds for Business: Trends and Problems of Measurement. In Conference of Research in Business Finance, (pp. 215-261). New York: National Bureau of Economics Research.

Frielinghaus, A., Mostert, B. \& Firer C. (2005). Capital structure and the firm's life stage. South African Journal of Business Management. 36(4), 9-18.

Gregory, B., Rutherford, M., Oswald, S. \& Gardiner, L. (2005). An Empirical Investigation of the Growth Cycle Theory of Small Firm Financing. Journal of Small Business Management. 43(4), 382-392. DOI: 10.1111/j.1540-627X.2005.00143.x

Harris, M. \& Raviv, A. (1991). The Theory of Capital Structure. The Journal of Finance. 46(1), 297355. DOI: $10.2307 / 2328697$

Harrison, R. (2013). Crowdfunding and the revitalization of the early stage risk capital market: catalyst or chimera. Venture Capital: An International Journal of Entrepreneurial Finance. 15(4), 283 311. DOI: $10.1080 / 13691066.2013 .852331$

Hass, P., Blohm, I. \& Leimeister, J.M. (2014). An Empirical Taxonomy of Crowdfunding Intermediaries. In: 35th International Conference on Information Systems, 14-17 December 2014. Auckland, New Zealand

Hornuf, L. \& Schwienbacher, A. (2015). The Emergence of Crowdinvesting in Europe. Discussion Paper. Retrieved February 22, 2017, from: https://epub.ub.uni-muenchen.de/21388/1/Hornuf\%20Schwienbacher\%20-\%20The\%20Emergence\%20of\%20Crowdinvesting\%20in\%20 Europe.pdf

Kraus, A. \& Litzenberger, R.H. (1973). A State-Preference Model of Optimal Financial Leverage. Journal of Finance: 28(4), 911-922. DOI: 10.2307/2978343

La Rocca, M., La Rocca, T. \& Cariola, A. (2009). Capital Structure Decisions During a Firm's Life Cycle. Small Business Economics. 37(1), 107-130. DOI: 10.18002/pec.v0i19.3585

Lasrado, L.A. \& Lugmayr, A. (2013). Crowdfunding in Finland - A new Alternative Disruptive Funding Instrument for Business. In the 17th International Academic MindTrek Conference on Making Sense of Converging Media, 01-04 October 2013 (pp. 194-201). New York: ACM

Massolution (2016). Crowdfunding Industry 2015 Report. Available at: http://reports.crowdsourcing. org/index.php?route=product/productandpath=20andproduct_id $=54$

Myers, S. C. (1984). The Capital Structure Puzzle. Journal of Finance. 39(3), 574-592. DOI: 10.1111/ j.1540-6261.1984.tb03646.x

Modigliani, F. \& Miller, M. (1963). Corporate Income Taxes and the Cost of Capital: A Correction. The American Economic Review. 53(3), 433-443.

Modigliani, F. \& Miller, M. (1958). The Cost of Capital, Corporation Finance and the Theory of Investment. The American Economic Review. 48(3), 261-297.

Mollick, E. (2014). The dynamics of crowdfunding: An exploratory study. Journal of Business Venturing. 29(1), 1-16. DOI: 10.1016/j.jbusvent.2013.06.005

Motylska-Kuzma, A. (2015). Cost of Crowdfunding as a Source of Capital for the Small Company. In Proceedings of International Academic Conferences, September 2015 (pp. 462-474). London: International Institute of Social and Economic Sciences

Paschen, J. (2017). Choose wisely: Crowdfunding through the stages of the startup life cycle. Business Horizons. 60(2), 179-188. DOI: 10.1016/j.bushor.2016.11.003

Penrose, E.T. (1952). Biological analogies in the theory of the firm. American Economic Review. 42(5), 804-819.

Ordanini, A., Miceli, L., Pizzetti, M. \& Parasuraman, A. (2011). Crowd-funding: transforming customers into investors through innovative service platforms. Journal of Service Management. 22(4), 443-470. DOI: 10.1108/09564231111155079 
Orsag, S. (2015). Poslovne financije. Zagreb: Masmedia, HUFA.

Orsag, S. \& Dedi, L. (2011). Budžetiranje kapitala: Procjena investicijskih projekata 2. izdanje. Zagreb: Masmedia.

Rajan, R. \& Zingales, L. (1998). Debt, Folklore and Cross-country Differences in Financial Structure. Journal of Applied Corporate Finance. 10(4), 102-107. DOI: 10.1111/j.1745-6622.1998. tb00313.x

Robb, A. \& Robinson, D. (2010). The Capital Structure Decisions of New Firms. Review of Financial Studies. 27(1), 153-179. DOI: 10.1093/rfs/hhs072

Rossi, M. (2014). The New Ways to Raise Capital: An Exploratory Study of Crowdfunding. International Journal of Financial Research. 5(2), 8-18. DOI: 10.5430/ijfr.v5n2p8

Scott, M. \& Bruce, R. (1987). Five Stages of Growth in Small Business. Long Range Planning. 20(3), 45-52. DOI: 10.1016/0024-6301(87)90071-9

Sogorb-Mira, F. \& López-Gracia, J. (2003). Pecking Order Versus Trade-Off: An Empirical Approach to the Small and Medium Enterprise Capital Structure. Retrieved February 19, 2017, from Social Science Research Network: https://ssrn.com/abstract=393160. DOI: 10.2139/ssrn.393160

Teixeira, G. \& Coutinho dos Santos, M. J. (2014). Do firms have financing preferences along their life cycle? Evidence from Iberia. Retrieved February 22, 2017, from Social Science Research Network: https://ssrn.com/abstract=676869. DOI: $10.2139 /$ ssrn.676869 